\title{
A SIMULATION OF OPTIMUM POWER REQUIREMENTS OF A COCOYAM CHIPPER
}

\author{
Ilkejiofor, M.C ${ }^{1 *}$, Ndirika, V.I.O' ${ }^{2}$, Onwuka, U. ${ }^{2}$ and Etoamailhe, U.J ${ }^{2}$ \\ ${ }^{1}$ Engineering Research Unit, National Root Crops Research Institute, Umudike Umuahia, \\ Abia State, Nigeria E-mail: mauikejiofor@yahoo.com \\ ${ }^{2}$ Department of Agricultural and Bioresources Engineering, Michael Okpara University of \\ Agriculture, Umudike Umuahia, Abia State, Nigeria
}

\begin{abstract}
A power requirement model was simulated at three factor interaction of process variables in order to select a combination of optimum crop and machine variables (cutting velocity, chipping slot area and feed rate. The computer simulation programme was used to identify the minimum chip loss for the various combinations of process variables and power requirement. The results obtained from simulation revealed that a minimum chip loss of $0.1667 \mathrm{~kg}$ was obtained for the cocoyam chipper at $4.91 \mathrm{~m} / \mathrm{s}$ cutting velocity, $0.0018 \mathrm{~m}^{2}$ chipping slot area and $0.056 \mathrm{~kg} / \mathrm{s}$ feed rate. The power requirement obtained at this level was $961.39 \mathrm{~W}$. These results gave room for good comparison with a minimum chip loss value of $0.1682 \mathrm{~kg}$ and $963.54 \mathrm{~W}$ power requirement obtained from the actual measurement at the same values of the parameters for the cocoyam chipper.
\end{abstract}

KEYWORDS: Simulation, Optimum, Power Requirement, Cocoyam, Chipper

\section{INTRODUCTION}

The purpose of modeling a physical system is to have a better understanding of the fundamental mechanism of that system, and to be able to establish the optimum conditions for the construction and operation of the system (Ndirika, 1997). Optimization of power requirement model for the cocoyam chipper helps to select combination of optimum variables needed for the design, construction and operation of the machine. This can be achieved by the use of predicting equations to identify the independent variables (cutting velocity, chipping slot area and feed rate) in the order of their contributions to the total variations on the dependent variable such as power requirements etc. Optimum conditions are those that produce the most favourable or most beneficial result from a system (Gajda and Biles, 1978). An algorithm or minimization technique using computer simulation programme can be developed to select combination of optimum variables. Optimization is aimed at maximizing or minimizing some functions relative to some set, often representing a range of choices available in a certain situation (Rockafellar, 2007). The function allows comparison of different choices for determining which might be "best". Optimization is applied to achieve minimal cost, maximal profit, best approximation, optimal design, optimal management or control. The schemes by which optimization techniques can be classified are: by number of independent variables, whether derivative or numerical methods can be employed and whether the problem is constrained or unconstrained. These and other considerations give rise to several different approaches to optimization (Ndirika et al., 2001). Excellent presentation and discussions of widely used techniques have previously been presented by Levi and Vol (1966); Biles and Swain (1980) and many others. Ndirika et al. (1996) developed a

* Corresponding author: Tel.: 08064216210; E-mail: mauikejiofor@yahoo.com 
mathematical model for predicting power requirement of selected stationary grain thresher. The model was validated with experimental results from stationary grain thresher. Ndirika et al. (2001) optimized the power requirement model developed in order to obtain optimum values of the independent variables at minimum grain loss for millet and sorghum threshers. Ikejiofor (2016) developed a mathematical model for predicting power requirement of a cocoyam chipper. However, there is still need to optimize the model in order to obtain optimum values of the independent variables at minimum chip loss for the cocoyam chipper. Therefore, the specific objective of this study is to develop an algorithm or minimization technique using computer simulation programme to select the best combination of the independent variables (cutting velocity, chipping slot area and feed rate) that yield optimum power requirement at minimum chip loss for the cocoyam chipper.

\section{MATERIALS AND METHODS}

\subsection{Model Description}

The model under consideration for optimization is the model developed by Ikejiofor (2016) for predicting power requirement of a cocoyam chipper. The model was developed by dimensional analysis using the concept of Buckingham's Pi theorem. The power requirement (P) can be predicted as given by the equation.

$$
\mathrm{P}=K_{p} V_{c} F+\left(W_{p} r_{p}\right) \frac{2 \pi \mathrm{N}}{60}
$$

Where, $\mathrm{K}_{\mathrm{p}}=$ power constant, $\mathrm{F}=$ chipping force $\left(\mathrm{kgm} / \mathrm{s}^{2}\right), \mathrm{V}_{\mathrm{c}}=$ cutting velocity $(\mathrm{m} / \mathrm{s}), W_{p}=$ weight of plate $(\mathrm{N}), r_{p}=$ radius of chipping plate $(\mathrm{m}), \mathrm{N}=$ revolutions per minute.

The power constant $\left(\mathrm{K}_{\mathrm{p}}\right)$ in the equation was determined by linearizing $\mathrm{Pi}_{1}$ and $\mathrm{Pi}_{4}$, which are $\frac{P_{c} W_{c}{ }^{4 / 3} \beta^{2 / 3}}{F_{r}{ }^{3}}$ and $\frac{V_{c} F W_{c}{ }^{4 / 3} \beta^{2 / 3}}{F_{r}{ }^{3}}$ respectively from the developed model by the method of least squares using data from available literature (Bolaji et al., 2008; Ogundipe et al., 2011; Oladeji, 2014; Aji et al., 2013). The slope of the line of best fit gives the value of the power constant, $\mathrm{K}_{\mathrm{p}}$ which was found to be 0.99 as presented in figure 1 .

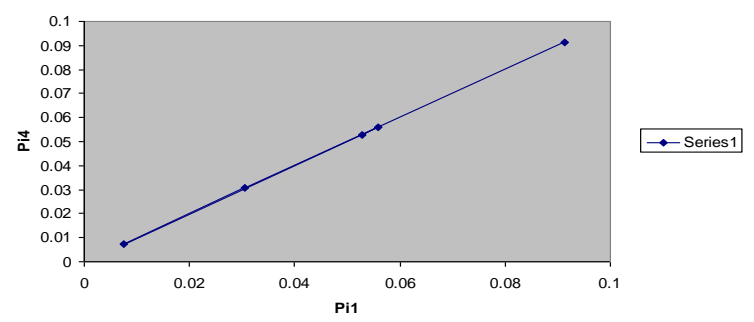

Fig. 1: Determination of power constant, $\mathrm{K}_{\mathrm{p}}$

\subsection{Formulation of optimization function}

Any optimization formulation as stated by Ndirika (1997) and Babashani (2008) is characterized by:

i. An objective function stating the quantity to be minimized or maximized and its functional dependence from the design variables, and

ii. The constraints on the design variables under which an optimum is to be searched. This can be expressed mathematically as follows: 


$$
\begin{aligned}
& \text { Optimize } Y_{o}=g_{o}\left(X_{1}, X_{2}, \ldots \ldots ., X_{n}\right) \\
& \quad \begin{array}{l}
\text { Subject to: } \\
\boldsymbol{a}_{o}\left\langle\boldsymbol { X } _ { 1 } \left\langle\boldsymbol{b}_{\boldsymbol{i}}, \quad i=1,2,3, \ldots \ldots . n\right.\right.
\end{array}
\end{aligned}
$$

Where,

$Y_{o}=$ objective function

$g_{o}=$ some relationship between $Y_{o}$ and $X_{1}$

$X_{i}=$ design variables

$a_{o}, b_{i}=$ lower and upper bounds respectively

For this study, the objective function considered is the minimization of chip loss which helps to determine the optimum levels of the power requirement and the design variables under consideration that results to minimum chip loss. A measure of total chip loss (TCL) was obtained using the total chip loss model equation developed by Ikejiofor (2016) as:

$\mathrm{TCL}=W_{1}-K_{c}\left[\frac{V_{c} \beta_{d}{ }^{2} S_{s}{ }^{2} F}{\left(1-M_{c}\right)^{2} F_{r}^{2}}\right] t$

Where, $\mathrm{W}_{1}=$ initial weight of cocoyam corms used, $\mathrm{kg}, \mathrm{K}_{\mathrm{c}}=$ capacity constant $\left(2.3298 \times 10^{-7}\right)$, $\mathrm{V}_{\mathrm{c}}=$ cutting velocity $(\mathrm{m} / \mathrm{s}), \beta_{d}=$ bulk density (dry basis) $\left(\mathrm{kg} / \mathrm{m}^{3}\right), \mathrm{S}_{\mathrm{s}}=$ chipping slot area $\left(\mathrm{m}^{2}\right), \mathrm{F}=$ chipping force $\left(\mathrm{kgm} / \mathrm{s}^{2}\right), \mathrm{F}_{\mathrm{r}}=$ feed rate $(\mathrm{kg} / \mathrm{s}), \mathrm{M}_{\mathrm{c}}=$ moisture content (decimal) and $\mathrm{t}$ $=$ chipping time (sec.). The design variables used in the optimization are cutting velocity $\left(\mathrm{V}_{\mathrm{c}}\right)$, chipping slot area $\left(\mathrm{S}_{\mathrm{s}}\right)$ and the feed rate $\left(\mathrm{F}_{\mathrm{r}}\right)$. The lower and upper limits of the design variables used are as follows: i) $3.93 \leq \mathrm{V}_{\mathrm{c}} \leq 4.91(\mathrm{~m} / \mathrm{s})$, ii) $0.0014 \leq \mathrm{S}_{\mathrm{s}} \leq 0.0018\left(\mathrm{~m}^{2}\right)$ and iii) $0.056 \leq \mathrm{F}_{\mathrm{r}} \leq 0.06(\mathrm{~kg} / \mathrm{s})$. The optimum values were computed using visual basic computer simulation programme at three factor interactions of the process variables: $3 \times 3 \times 3$ levels of variable combination ( 3 levels of cutting velocity, 3 levels of chipping slot area and three levels of feed rate). A maximum chip loss of 5\% was used in the optimization process. The computer simulation programme flowchart is shown in Figure 2, and the crop and operating

\begin{tabular}{|c|c|c|c|c|}
\hline \multirow{3}{*}{ S/No } & \multirow{3}{*}{ Parameters } & \multirow{2}{*}{\multicolumn{3}{|c|}{ Values/Levels }} \\
\hline & & & & \\
\hline & & 1 & 2 & 3 \\
\hline 1 & Cutting speed, N (rpm) & 300 & 350 & 375 \\
\hline 2 & Cutting Velocity, $\mathrm{V}_{\mathrm{c}}(\mathrm{m} / \mathrm{s})$ & 3.93 & 4.58 & 4.91 \\
\hline 3 & $\begin{array}{lll}\begin{array}{l}\text { Chipping } \\
\left(\mathrm{Kgm}^{2} \mathrm{~s}^{2}\right)\end{array} & \text { force, } & \mathrm{F} \\
\end{array}$ & 193.68 & 193.68 & 193.68 \\
\hline 4 & Feed Rate, Fr (kg/s) & 0.056 & 0.058 & 0.06 \\
\hline 5 & $\begin{array}{l}\begin{array}{l}\text { Chipping } \\
\left(\mathrm{m}^{2}\right)\end{array} \\
\text { Slot Area, Ss }\end{array}$ & 0.0014 & 0.0016 & 0.0018 \\
\hline 6 & Moisture Content, $\mathrm{M}_{\mathrm{c}}(\%)$ & 52.39 & 52.39 & 52.39 \\
\hline
\end{tabular}
conditions for the chipper are presented in Table 1.

Table 1: Crop and Operating Conditions for the Chipper 
DOI : https://dx.doi.org/10.26808/rs.ed.i8v4.06

International Journal of Emerging Trends in Engineering and Development

Issue 8, Vol.4 (June-July 2018)

Available online on http://www.rspublication.com/ijeted/ijeted_index.htm

ISSN 2249-6149

\begin{tabular}{|l|l|l|l|l|}
\hline 7 & $\begin{array}{l}\text { Bulk density, } \beta_{d} \text { dry basis } \\
\left(\mathrm{kg} / \mathrm{m}^{3}\right)\end{array}$ & 231.28 & 231.28 & 231.28 \\
\hline 8 & $\begin{array}{l}\text { Weight of Chipping Plate, } \\
\mathrm{W}_{\mathrm{p}}(\mathrm{kg})\end{array}$ & 2.67 & 2.67 & 2.67 \\
\hline 9 & $\begin{array}{l}\text { Radius of Chipping Plate, } \\
\mathrm{r}_{\mathrm{p}}(\mathrm{m})\end{array}$ & 0.19 & 0.19 & 0.19 \\
\hline 10 & $\begin{array}{l}\text { Initial Weight of Tubers, } \\
\mathrm{W}_{1}(\mathrm{~kg})\end{array}$ & 5.6 & 5.8 & 6.0 \\
\hline
\end{tabular}

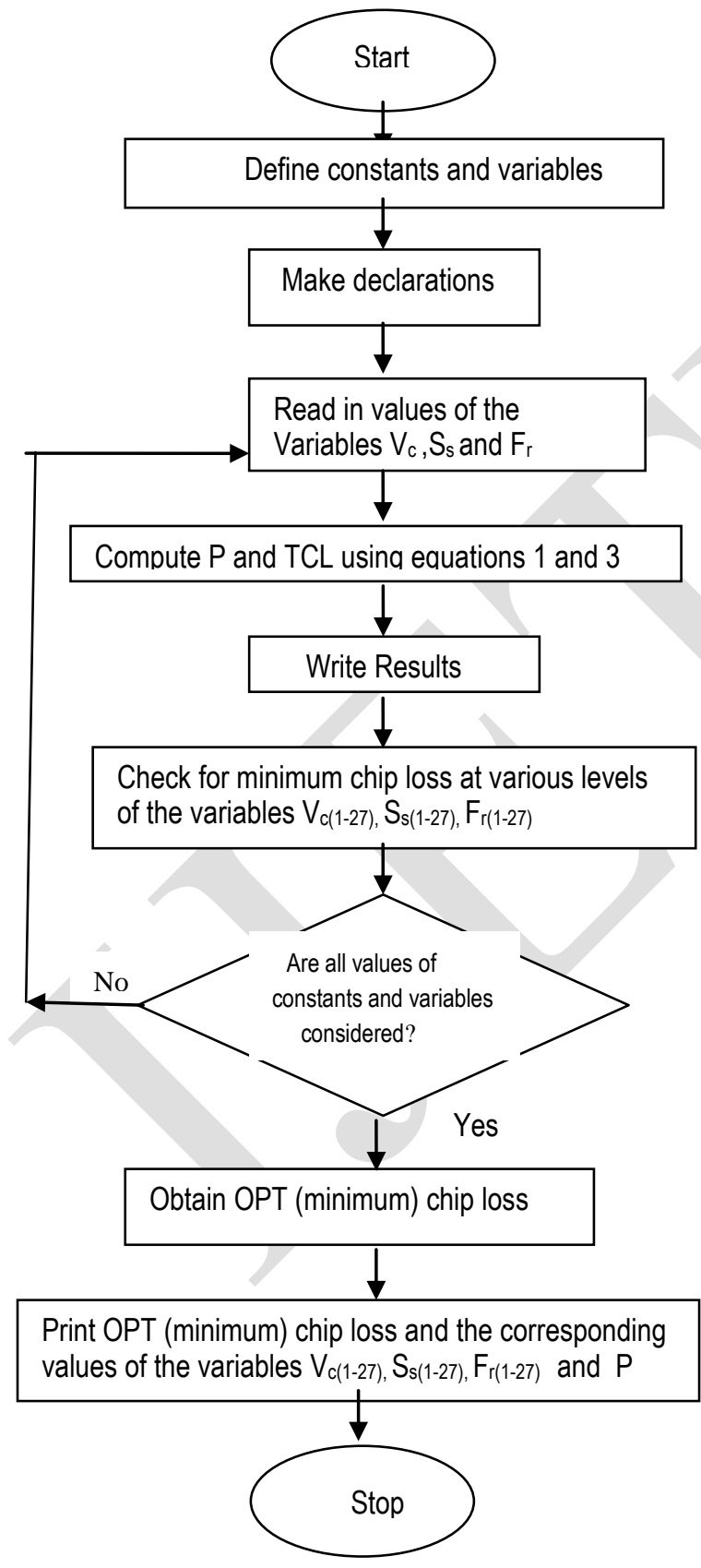

Fig. 2: Flowchart for optimization simulation programme 


\subsection{Experiments}

Minimum chip loss (MCL) and power requirement obtained from simulation were compared with the experimental data from the developed cocoyam chipper using the optimum parameters. Moisture contents of the sliced cocoyam corms were determined by oven drying the cocoyam samples at a temperature of $75^{\circ} \mathrm{C}$ for 24 hours. The moisture content in wet basis for the various oven dried samples was calculated using the formula provided by Kajuna et al. (2001). The bulk density was determined as the ratio between the mass of the cocoyam corms in a container to its volume (Kaleemullah and Kailappan, 2003). The wattmeter whose wattage values ranged between 0 and 4800 watts was used for measuring the power requirements. Total chip loss was evaluated by determining the amount of chips that could not be recovered from the machine after chipping. This was mathematically expressed as:

Total chip loss $(\mathrm{TCL})=\mathrm{W}_{1}-\left(\mathrm{W}_{2}+\mathrm{W}_{3}\right)$

Where, $\mathrm{W}_{1}=$ input weight $(\mathrm{kg}), \mathrm{W}_{2}=$ output weight for normal chips $(\mathrm{kg}), \mathrm{W}_{3}=$ output weight of crushed tubers $(\mathrm{kg}), \mathrm{W}_{2}+\mathrm{W}_{3}=$ total mass of chips produced.

\section{RESULTS AND DISCUSSION}

The results obtained as shown in Table 2 revealed that total chip loss (TCL) reduced with increase in chipping slot area for both simulated and measured results. From the three levels of the chipping slot areas considered in this study, it is only the minimum chip loss obtained at $0.0018 \mathrm{~m}^{2}$ slot area that was less than the tolerable value $(5 \%)$. This implies that chipping operations carried out at $0.0018 \mathrm{~m}^{2}$ slot area are adequate. The optimum feed rate, cutting velocity and chipping slot area obtained from the table were $0.056 \mathrm{~kg} / \mathrm{s}, 4.91 \mathrm{~m} / \mathrm{s}$ and 0.0018 $\mathrm{m}^{2}$ respectively. The power requirement of the cocoyam chipper obtained at the resulting values of optimum feed rate, cutting velocity and chipping slot area was $961.34 \mathrm{~W}$. It was observed from the table that the values of the total chip loss reduced with increase in chipping slot area. The results obtained also revealed that the values of the total chip loss and power requirement obtained for both simulated and measured data were in close agreement as shown in Figures 3 and 4, respectively.

Table 2: Optimum Parameters and Power Requirement Corresponding to Minimum Chip Losses for the Chipper

\begin{tabular}{|l|l|l|ll|ll|}
\hline $\mathrm{S}_{\mathrm{s}}\left(\mathrm{m}^{2}\right)$ & $\mathrm{V}_{\mathrm{c}}(\mathrm{m} / \mathrm{s})$ & $\mathrm{F}_{\mathrm{r}}(\mathrm{kg} / \mathrm{s})$ & \multicolumn{2}{|c|}{$\mathrm{P}(\mathrm{Watt})$} & \multicolumn{2}{|c|}{ TCL $(\mathrm{kg})$} \\
& & & Simu. & Meas. & \multicolumn{2}{c|}{ Simu. Meas. } \\
\hline 0.0014 & 4.91 & 0.056 & 961.38 & 963.54 & 2.313 & 2.304 \\
\hline 0.0016 & 4.91 & 0.056 & 961.38 & 963.54 & 1.307 & 1.328 \\
\hline 0.0018 & 4.91 & 0.056 & 961.38 & 963.54 & 0.167 & 0.168 \\
\hline
\end{tabular}

Simu. $=$ Simulated, Meas. $=$ Measured 
Predicted $=0.002+1.002$ measured

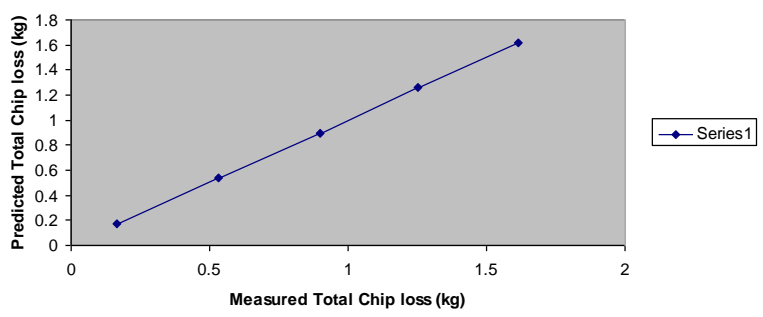

Fig. 3: Predicted Vs Measured Total Chip Loss (kg)

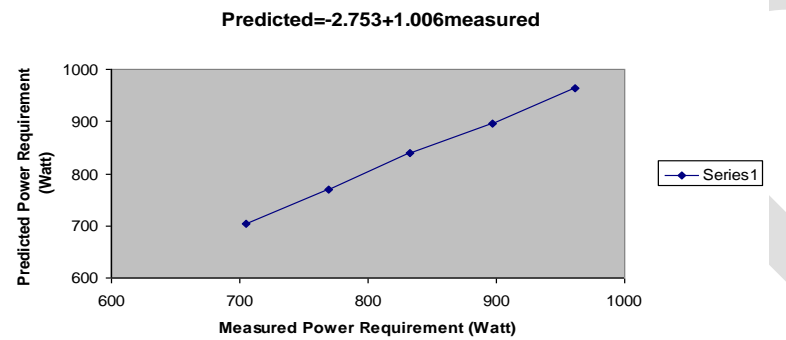

Fig. 4: Predicted Vs Measured Power Requirement (Watt)

\section{CONCLUSION}

The study revealed that power requirement corresponding to optimum crop and machine variables (cutting velocity, chipping slot area and feed rate) with minimum chip loss for the cocoyam chipper can be achieved by simulation. The optimum power requirement of 961.34 W was obtained with minimum chip loss of $0.167 \mathrm{~kg}$ at $0.0018 \mathrm{~m}^{2}$ chipping slot area, 0.056 $\mathrm{kg} / \mathrm{s}$ feed rate and $4.91 \mathrm{~m} / \mathrm{s}$ cutting velocity.

\section{REFERENCES}

1. Aji, I.S; James, E; Ejovwoke, A. and Mshelia, D.A.(2013). Development of an Electrically Operated Cassava Slicing Machine. Arid Zone Journal of Engineering, Technology and Environment; Vol.9. Pg 90 - 95.

2. Babashani, B. (2008). Mathematical Modeling of the Spray Penetration and Deposition on Orchard Tree Canopies. PhD. Dissertation, Department of Agricultural Engineering, Ahmadu Bello University Zaria, Nigeria.

3. Biles, W.E. and Swain, J.J. (1980). Optimization and Industrial Experimentation. Third Edition. Wiley Inter-Science Publication. New York.

4. Bolaji, B.O; Adejuyibe, S.B. and Ayodeji, S.P.(2008). Performance Evaluation of a Locally Developed Cassava chipping Machine. South African Journal of Industrial engineering, Vol. 19 (1), Pg $169-178$.

5. Gajda, W. J. and Biles, W.E. (1978). Engineering Modeling and Computation. Houghton Mifflin Company, Boston.

6. Ikejiofor, M.C. (2016). Modeling and Optimization of Performance Parameters for Chipping Process of a Cocoyam Chipping Machine. PhD. Dissertation. Department of Agricultural and Bioresources Engineering. Michael Okpara University of Agriculture, Umudike

7. Kajuna, S.T; Silajo, V.C; Mkenda, A. and Makungu, P.J. (2001). Thin Layer Drying of Diced Cassava Roots. African Journal of Science and Technology (AJST) 2 (2): Pg 94 100. 
www.ajol.info/index.php/ajst/article/downloadphp/ajst/article/download/44677/28181.

8. Kaleemullah, S. and Kailappan, R. (2003). Geometrics and Morphometrics. Properties of Chillies. International Journal of Food Properties, Vol. 6. Pg 481 - 498.

9. Levi, A. and Vol. T.P. (1966). Recent Advancement in Optimization Techniques.Second Edition. John Wiley and Sons, Co. New York.

10. Ndirika, V.I.O; Asota, C.N. and Mudiare, O.J. (1996). Predicting the Power Requirement and Threshing Efficiency of Stationary Grain Thresher using Mathematical Models. Journal of Agricultural Engineering and Technology 4.Pg. 39 - 49.

11. Ndirika, V. I. O. (1997). Modeling the Performance of Selected Stationary Grain Threshers. PhD. Thesis, Department of Agricultural Engineering, Ahmadu Bello University Zaria, Nigeria.

12. Ndirika, V.I.O; Asota, C.N; Yiljep, Y.D. and Mudiare, O.J. (2001). Optimizing Power Requirement Model of Selected Grain Threshers. International Journal of Research in Science and Education, Vol. 1 (1). Pg 135 - 141

13. Ogundipe, O.S.; Oyelade, O.A. and Farounbi, J.A.(2011). Development and Performance Evaluation of a Cassava Chipping Machine. Journal of Agricultural Engineering and Technology, Vol.19 (No. 2). Pg 59 - 72.

14. Oladeji, J.T. (2014). Design, Fabrication and Testing of Cassava Chipping Machine. World Rural Observations 2014; 6 (2), Pg 44 - 47.

15. Rockafeller, R.T. (2007). Fundamentals of Optimization. Lecture Notes 2007. Department of Mathematics. University of Washington, Seattle. 